Article

\title{
Selenium Uptake by Lettuce (Lactuca sativa L.) and Berseem (Trifolium alexandrinum L.) as Affected by the Application of Sodium Selenate, Soil Acidity and Organic Matter Content
}

\author{
Myrto Tsioubri ${ }^{1}$, Dionisios Gasparatos ${ }^{1, * \mathbb{C}}$ and Maria Economou-Eliopoulos ${ }^{2}$ \\ 1 Department of Natural Resources Management and Engineering, Agricultural University of Athens, Iera \\ Odos 75, 11855 Athens; Greece; myrtotsioubri@aua.gr \\ 2 Faculty of Geology and Geoenvironment, National and Kapodistrian University of Athens, Zografou, 15784 \\ Athens, Greece; econom@geol.uoa.gr \\ * Correspondence: gasparatos@aua.gr
}

Received: 13 March 2020; Accepted: 9 May 2020; Published: 9 May 2020

\begin{abstract}
Selenium deficiency in humans and animals can be reduced through dietary supplementation. Therefore, Se biofortification strategy is important in food plants and pastures. In this study, the effects of selenium (Se) addition ( $4 \mathrm{mg} \mathrm{Se} / \mathrm{kg})$ as sodium selenate $\left(\mathrm{Na}_{2} \mathrm{SeO}_{4}\right)$ on lettuce (Lactuca Sativa L.) and berseem cultivation (Trifolium alexandrinum L.) were investigated. The experiment was conducted under greenhouse conditions with two different soil types, an acidic ( $\mathrm{pH}=$ 6.3) and an alkaline $(\mathrm{pH}=8.0)$ soil with different organic matter content, in a completely randomized design. The results indicated higher Se content in berseem cultivated on acidic soil. It was also observed a significant reduction $(\sim 45 \%)$ in plant biomass of lettuce in the acidic soil combined with Se application. The results showed that leaf Se content was negatively correlated with soil organic matter. The decreased Se content in plants cultivated on the alkaline soil with high organic matter content support that the effect of $\mathrm{pH}$ on Se uptake decreased as the soil organic matter content increased.
\end{abstract}

Keywords: selenium; soil properties; $\mathrm{pH}$; organic matter; sodium selenate

\section{Introduction}

Selenium (Se) is considered a mineral micronutrient, having characteristic physical and chemical properties, which are intermediates of metals and non-metals [1]. In the natural environment, Se occurs in four oxidation states with valences $6+, 4+, 2$ - and 0 (elemental form). The Se effects on human health were identified for the first time in 1957, almost a century after its discovery. It has been identified as an essential trace element for humans and animals and its adequacy may prevent hepatic necrosis due to lack of vitamin E, cardiovascular disease, muscle disorders, cancers, and also seems to play an important role in male fertility [2-4]. However, since the difference between Se dietary deficiency $(<40 \mu \mathrm{g} /$ day) and toxicity ( $>400 \mu \mathrm{g} /$ day $)$ is narrow, human and animal intake requires careful control. In addition to the beneficial effects on human health, Se is an important trace element for the daily diet of the animals, too. A lack of Se can significantly affect production efficiency and animal health, with a high mortality rate among offspring, resulting from degenerative changes in myocardium. Selenium is found in trace amounts in the Earth's crust and mantle and characterized by unequal distribution worldwide. In soils, Se may be present naturally because of weathering processes ranging between 0.01 and $2 \mathrm{mg} / \mathrm{kg}$, with a world mean of $0.4 \mathrm{mg} / \mathrm{kg}$ and/or anthropogenic activities, such as mining and refining processes of sulfide ores. Soil in many parts of the world has low Se concentrations $(<0.6 \mathrm{mg} / \mathrm{kg})$, including large areas of Scandinavia, North 
America, New Zealand, Australia and China [5]. The lack of Se in soils and the crops grown on these soils results in approximately 500-1000 million people worldwide being affected by Se malnutrition. This makes them susceptible to health problems, such as growth retardation, immune dysfunction and increases the risk of cancer and lymphoma [6,7]. Se concentration in sedimentary rocks, especially shales and coal is much higher than in igneous rocks [8]. In Greece, the Se content in sulfide ores of Cyprus type exhibits a wide variation from a few tens to hundreds $\mathrm{mg} / \mathrm{kg}$ in the Othrys, Veria and Argolis ophiolites while in the Pindos (Kondro) ophiolite complex the Se content ranges from 160 to $1900 \mathrm{mg} / \mathrm{kg}$ (average $990 \mathrm{mg} / \mathrm{kg}$ ) [9,10]. The mobility and bioavailability of soil Se depends by complex chemical and biochemical process and is controlled primary by the redox potential (Eh), the percentage of soil organic matter (SOM), the clay percentage and the soil acidity $(\mathrm{pH})$ [11].

The plant species constitute a link between soil types and animal species on the uptake and transfer of Se to the higher nutritional levels. Plants according to their ability to accumulate Se in their tissues are divided into three major categories: i) the hyperaccumulators plants, with concentration levels ranging from 1000 to $10,000 \mathrm{mg} / \mathrm{kg}$, ii) the secondary accumulators or indicators, which rarely exceed a few hundred to a few thousand $\mathrm{mg} / \mathrm{kg}$ Se concentration in their tissues; and iii) non-accumulators (types of grass, trees and some weeds), which generally accumulate less than $25 \mathrm{mg} / \mathrm{kg}[12,13]$.

Plants grown in soil fertilized with Se will be enriched in Se, and these plants have a critical role in transferring Se from soil into the food chain, either be used directly for human consumption, or as animal feed. The effectiveness of that common management practice can produce Se-rich products that may be regarded as functional foods. For example, Se fertilization has been proved to be an efficient method of increasing Se content in forages and cereals [14]. Since the most important source of Se is diet, in recent years, agronomic Se-biofortification strategies have been proposed as an effective and safe mean to increase human and animal Se intake. Finland has conducted a Se fertilization program, where addition of $15 \mathrm{mg} \mathrm{Se} / \mathrm{kg}$ in multi-element fertilizers has been mandatory since 1984 [15]. On the other hand, since a limited fraction of applied Se is utilized by plants, usually less than $10 \%$, Se overfertilization may lead to leaching and contamination of groundwater or surface water via runoff. In this context, gaining a comprehensive understanding of the behavior of added Se in soil-plant system is necessary under different pedoclimatic environments.

According to Gupta and Gupta (2017) [16], Greece are reported to have Se deficient areas, whereas Se containing fertilizers with added soluble selenate or selenite salts are, neither imported, nor manufactured in the country. Nevertheless, the mean Se content of hard and soft wheat, barley, oats, rye and corn from almost 100 different locations of Greece was $0.29 \pm 0.19,0.21 \pm 0.12,0.16 \pm 0.10$, $0.14 \pm 0.10,0.19 \pm 0.10$, and $0.12 \pm 0.08 \mathrm{mg} / \mathrm{kg}$ (on a dry weight basis), respectively [17].

In this context, the aim of this study was to evaluate the effect of selenate $\left(\mathrm{SeO}_{4}{ }^{2-}\right)$ applied as inorganic fertilizer on the biomass and Se uptake of two different crops, Lactuca Sativa L. (vegetable crop) and Trifolium alexandrinum L. (animal-feed crop) grown on two different soil types (acidic and alkaline soil) under greenhouse conditions. Moreover, this study highlights the role of soil properties, i.e., $\mathrm{pH}$ and SOM content in influencing Se concentration in lettuce and berseem plants for human and animal nutrition.

\section{Results and Discussion}

The properties of the two studied soils at the start of the experiment are summarized in Table 1.

The soils are fine textured with contrasting chemical properties. Soil organic matter levels are medium to high in both soils, but over double in alkaline soil, which contains also significant amounts of carbonates as expected. Compared to alkaline soil, the concentrations of exchangeable cations are lower in acidic soil. 
Table 1. Selected physicochemical properties of the soils at the start of the experiment.

\begin{tabular}{ccc}
\hline Parameter & Acidic Soil & Alkaline Soil \\
\hline Texture & Clay & Clayloam \\
$\mathrm{CaCO}_{3}(\%)$ & - & 20.4 \\
Organic matter $(\%)$ & 2.1 & 5.0 \\
$\mathrm{pH}(1: 1 \mathrm{~s} / \mathrm{w})$ & 6.3 & 8.0 \\
Exchangeable $\mathrm{K}\left(\mathrm{cmol}(+) \mathrm{kg}^{-1}\right)$ & 0.33 & 4.58 \\
Exchangeable Ca $\left(\mathrm{cmol}(+) \mathrm{kg}^{-1}\right)$ & 1.73 & 5.35 \\
Exchangeable $\mathrm{Mg}\left(\mathrm{cmol}(+) \mathrm{kg}^{-1}\right)$ & 0.16 & 3.70 \\
Available P $(\mathrm{mg} / \mathrm{kg})$ & 12 & 65 \\
Available Se $(\mathrm{mg} / \mathrm{kg})$ & $<0.004$ & $<0.004$ \\
\hline
\end{tabular}

In the greenhouse experiment, lettuce growth was clearly poorer in the pots filled with acidic soil than in the pots filled with the alkaline. Aboveground biomass (fresh weight) in the acidic soil was close to $1 / 4$ the amounts of those in the alkaline soil. This poor plant growth was most likely due to less favorable conditions in the acidic soil that developed during cultivation. According to the ANOVA results in Table 2, all the experimental factors have a marked impact on the fresh weight of leaves. Soil type and Se treatment significantly affected the fresh weight of leaves at $p<0.001$, while cultivation effect is significant at $p<0.01$. As shown in Figure 1a, a significant negative relationship of soil $\mathrm{pH}$ (as expressed by soil type) with the fresh weight of lettuce was found, suggesting that under acidic conditions the growth of lettuce was significantly restricted. Conversely, for berseem crop the effect of soil type was less important.

Table 2. Analysis of Variance for effects of various factors on fresh weight of leaves.

\begin{tabular}{cccccc}
\hline Source & $\begin{array}{c}\text { Sum of } \\
\text { Squares }\end{array}$ & Df & Mean Square & F-Ratio & $p$-Value \\
\hline MAIN & & & & & \\
EFFECTS ${ }^{1}$ & & & & & \\
A:Cultivation & 617.44 & 1 & 617.44 & 10.32 & 0.0036 \\
B:Soil & 7416.7 & 1 & 7416.7 & 43.97 & 0.0000 \\
C:Treatment & 2597.77 & 1 & 2597.77 & 54.02 & 0.0000 \\
INTERACTIONS & & & & 23.57 & 0.0001 \\
AB & 3231.68 & 1 & 3231.68 & 14.88 & 0.0007 \\
AC & 1410.42 & 1 & 1410.42 & & \\
BC & 890.53 & 1 & 890.53 & & \\
RESIDUAL & 1495.69 & 25 & 59.8275 & & \\
TOTAL & 16480.9 & 31 & & & \\
(corrected) & & & & & \\
\hline
\end{tabular}

${ }^{1}$ Cultivation (Lettuce - Berseem). Soils (Acidic - Alkaline). Treatments (Control - Treatment Se).

Lettuce plants exposed to sodium selenate exhibited a $45 \%$ decrease in fresh weight, when compared with control plants, while the reduction for berseem plants was only $10 \%$ (Figure 1b). Our results are in accordance with Ramos et al. [18] who observed an inhibitory effect of Se when lettuce plants treated with high concentrations of sodium selenate ( $>16 \mu \mathrm{mol} / \mathrm{L})$. Mora et al. [19], observed that the applications $>40 \mathrm{~g} \mathrm{Se} /$ ha decreased the shoot growth of white clover (Trifolium repens $\mathrm{L}$.) by $22 \%$, whereas application at the rate of $60 \mathrm{~g} \mathrm{Se} /$ ha resulting to a decrease by more than $60 \%$ compared to control plants. Several studies have also shown a significant decrease of plant growth in different crops with increase in Se plant content. For example, Soltanpour and Workman [20], reported a decrease by $10 \%$ in alfalfa yield and Banuelos et al. [21], indicated that yield of canola, barley and indian mustard decreased by $25 \%, 20 \%$, and $16 \%$, respectively, grown on Se treated soil. 

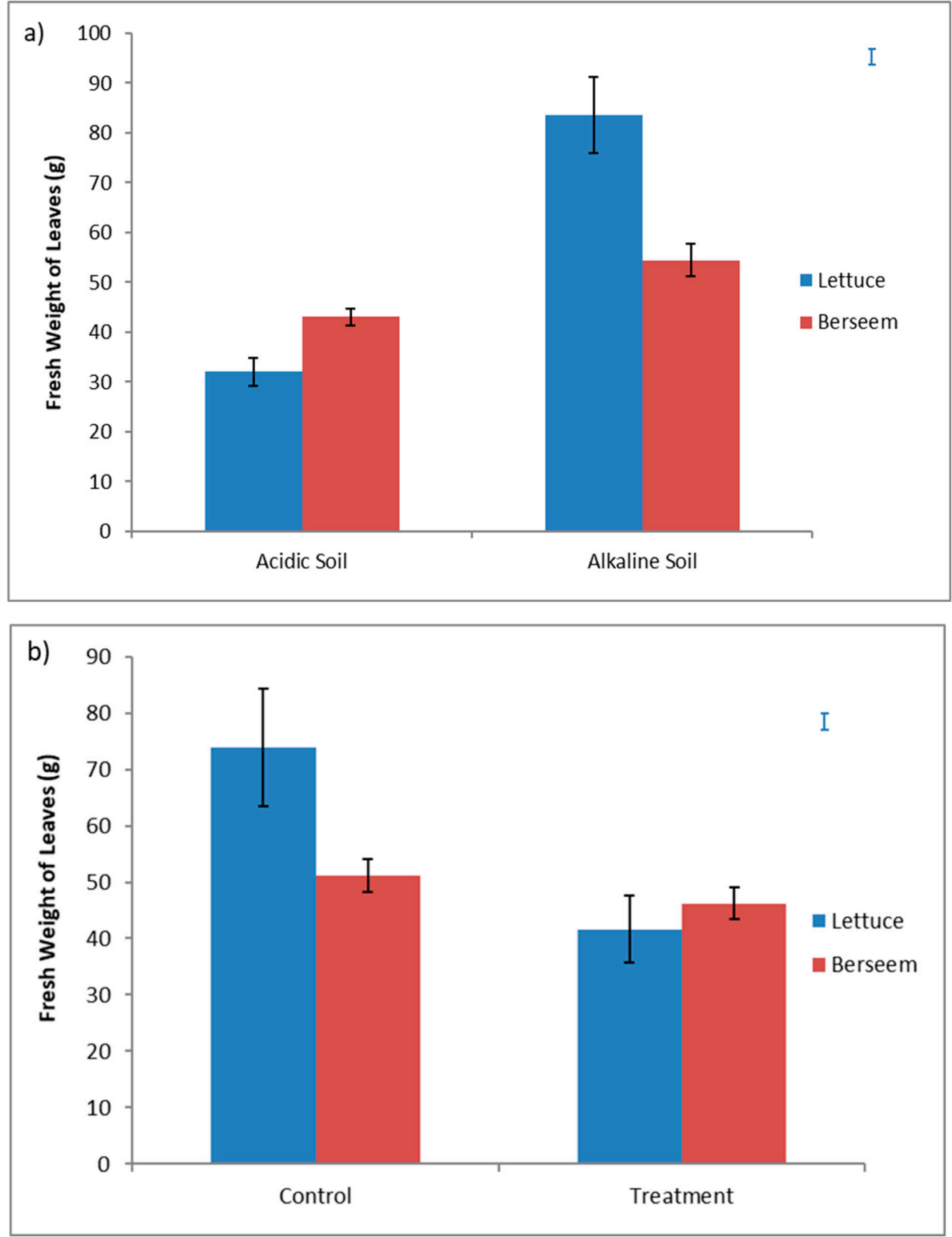

Figure 1. Effects of various factors on fresh weight of leaves; (a) cultivation vs. soil type; (b) cultivation vs. Se treatments. In each column the bar on it represents the standard error of the mean. Bars at the right side of the graphs are the standard error of the ANOVA analysis.

The results of the performed ANOVA showed the effects of Se application, soil type, cultivation, and tissues on Se plant content. (Table 3). In treated samples, the Se plant content independently of the cultivation, was higher in the acidic than the alkaline soil, whereas the control plants were not affected by the soil type (Figure 2a). Dimes et al. [22], reported that maximum Se uptake by Trifolium subterraneum was observed at $\mathrm{pH}$ 6.7. 
Table 3. Analysis of Variance for effects of various factors on Se content.

\begin{tabular}{cccccc}
\hline Source & $\begin{array}{c}\text { Sum of } \\
\text { Squares }\end{array}$ & Df & Mean Square & F-Ratio & $p$-Value \\
\hline MAIN & & & & & \\
EFFECTS & & & & & \\
A:Cultivation & 1587.75 & 1 & 1587.75 & 17.06 & 0.0001 \\
B:Soils & 2733.08 & 1 & 2733.08 & 29.37 & 0.0000 \\
C:Tissues & 871.347 & 1 & 871.347 & 9.36 & 0.0035 \\
D:Treatments & 4767.74 & 1 & 4767.74 & 51.23 & 0.0001 \\
INTERACTIONS & & & & 0.0138 \\
AB & 1602.0 & 1 & 1602.0 & 17.22 & 0.0001 \\
AC & 603.931 & 1 & 603.931 & 18.01 & 0.0001 \\
AD & 1676.4 & 1 & 1676.4 & 17.13 & 0.0000 \\
BC & 1594.01 & 1 & 1594.01 & 8.68 & 0.0048 \\
BD & 2726.33 & 1 & 2726.33 & & \\
CD & 807.767 & 1 & 807.767 & & \\
RESIDUAL & 4932.04 & 53 & 93.0574 & & \\
TOTAL & 27369.3 & 63 & & & \\
(Corrected) & & & & &
\end{tabular}

Se fertilization has been shown to significantly enhance Se concentrations in lettuce and berseem plant and variance analyses indicated that the increased Se concentration of the treated plants was statistically significant, when compared to the control samples (Figure $2 b$ ).

The form of Se added, selenate, is weakly adsorbed by electrostatic forces of attraction forming outer-sphere surface complexes, and therefore, is more exchangeable, resulting in higher plant availability and potential for leaching in relation to selenite. Se concentrations in lettuce leaves ranged between 2 and $17 \mathrm{mg} / \mathrm{kg}$ dry weight, whereas for roots the treatment resulted in Se concentrations between 1.8 and $7.5 \mathrm{mg} / \mathrm{kg}$ dry weight. Se concentrations in berseem leaves ranged between 4 and $54 \mathrm{mg} / \mathrm{kg}$ dry weight while for roots the Se addition resulted in Se concentrations between 3.0 and $18 \mathrm{mg} / \mathrm{kg}$ dry weight. These results indicated that the Se accumulation in plant tissues was higher in berseem than lettuce plants (Figure 2b), due to the ability of Fabaceae to absorb high levels of Se [23]. Fabaceae species have an elevated protein content in relation to Compositae (Lactuca Sativa L.) and Se in these species can substitute for $S$ in protein amino acids (cysteine and cystine), and therefore increased Se contents [24].

Apart from plant genotype, another factor that actively participates in the uptake of Se is the shape and type of the root system of plants. Lactuca sativa is characterized by tap root system, while Trifolium alexandrinum plants have fibrous root system, which occupies almost the whole soil volume, resulting in the increased possibility of Se uptake.

The high plant Se concentrations of this study are comparable with Se concentrations of plants grown on naturally Se-rich (seleniferous) soils. For example, Dhillon et al. [25], reported Se concentrations ( $\mathrm{mg} \mathrm{Se} / \mathrm{kg}$ dry weight) of 1.5-86.6 for raya (Brassica juncea Czern L.), 0.7-58.3 for wheat (Triticum aestivum L.) 0.7-58.3 for maize (Zea mays L.) and 1.5-4.6 for rice (Oryza sativa L.) when grown in alkaline seleniferous soils in north-western India. Recently, Fan et al. [26] observed that the addition of $30 \mathrm{mg} / \mathrm{kg}$ selenate increased the Se contents of leaves and roots of tobacco to 312.61 and $242.28 \mathrm{mg} / \mathrm{kg}$, respectively. For plant tissues, controls showed the same amount of Se independently cultivation. The above observations lead to the conclusion that significant changes in the Se concentrations of plant tissues, occurs in soils enriched with Se. Application of selenate to the soil resulted in a significant increase in the Se concentration in leaves, whereas the Se increments in root tissues were lower (Figure 2c). Several studies demonstrated that Se is mainly accumulated in plant shoot than in root [27]. As previously suggested by Krystofova et al. [28], a high Se content in 
leaves shows that inorganic Se is intensively transported from roots by the xylem to photosynthetically active organs. Moreover, according to Zhang [29] selenate forms like those used in our study are more easily transported to shoots, while selenite tends to accumulate in plant roots.
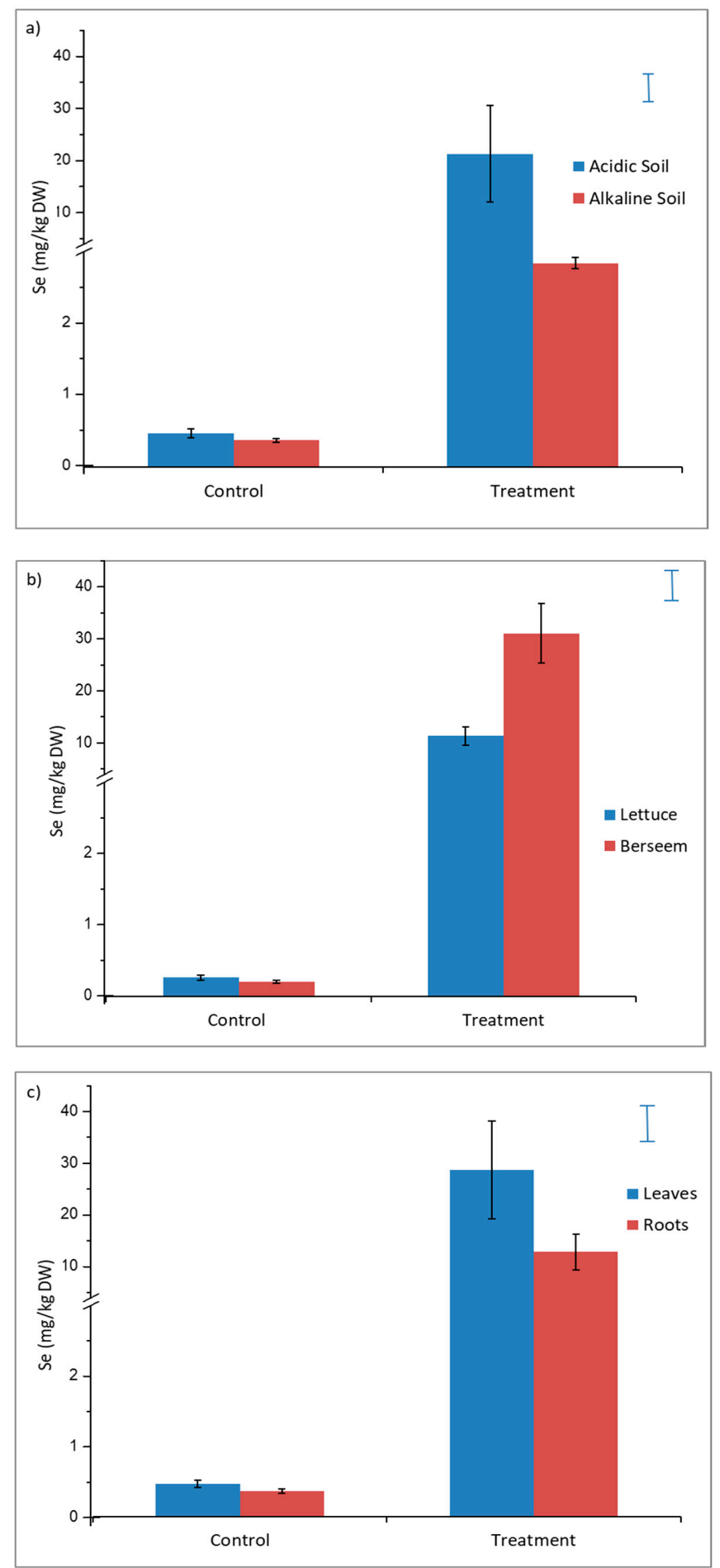

Figure 2. Effects of Se treatments (Control - Treatment Se); and (a) soil type; (b) cultivation; and (c) tissues independently of cultivation on plant Se content ( $\mathrm{mg} / \mathrm{kg}$ dry weight) In each column the bar on it represents the standard error of the mean. Bars at the right side of the graphs are the standard error of the ANOVA analysis. 
The influence of soil properties on leaf Se concentrations was investigated. Table 4 shows the negative relationship between SOM and plant Se content for lettuce and berseem cultivation. The correlation was strong in lettuce $(r=-0.86)$, but a lower content of SOM was strongly negatively correlated to a higher content of Se in the berseem $(r=-0.97)$.

Table 4. Correlation between leaf Se content and soil organic matter (SOM) content for lettuce and berseem plants.

\begin{tabular}{ccc}
\hline & SOM & Se Content \\
\hline Lettuce & 1 & $-0.86^{* *}$ \\
SOM & $-0.86^{* *}$ & 1 \\
Se content & 1 & $-0.97^{* * *}$ \\
Berseem & $-0.97^{* * *}$ & 1 \\
SOM & ${ }^{* *} p<0.01,{ }^{* * *} p<0.001$.
\end{tabular}

Soil organic matter, as an important soil component that retains Se, plays a very significant role in Se immobilization and influence the availability of Se to plants, especially in acidic soils [30,31]. The interaction of Se and soil organic matter may occur via various mechanisms: (i) Complexation of Se by high affinity sorption sites of organic matter [32]; (ii) microbial reduction to lower oxidation state enhancing incorporation into low-molecular-weight humic substances, proteins and amino acids [31]; and (iii) indirect complexation of Se by organic matter-metal complexes [32-34].

Sorting the data for the acidic and alkaline soils with respect to SOM levels allowed a comparison of the effect of SOM on Se uptake. Our results indicated that up to $90 \%$ of the variation in plant Se content in the greenhouse experiment could be explained by SOM content (Figure 3.). For both soil types, plants grown in the soils with the lower organic matter content took up more Se than those grown in the soils with high organic matter content. According to Table 5, an increase in SOM content from 1.4 to $4.5 \%$ led to a decrease in Se uptake from 78.4 to $9.4 \mathrm{mg} / \mathrm{kg}$ dry weight, representing a total decrease up to $88 \%$ for berseem cultivation. Similarly, Johnsson [11] reports that at soil pH 7, an increase of SOM from 1.5 to $39 \%$ resulted in significant decrease in Se uptake of $88 \%$, and $69 \%$ for wheat grain and rape, respectively.

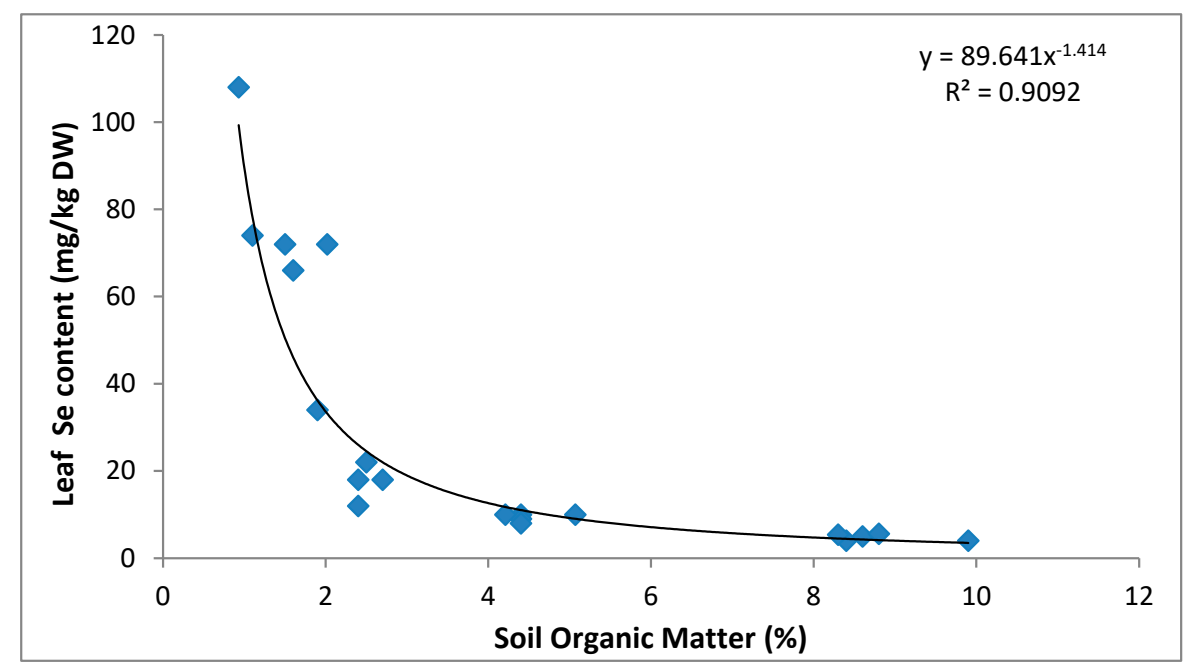

Figure 3. Relationship between soil organic matter and Se content of lettuce and berseem crops grown in soils with a $\mathrm{pH}$ range of 6.1 to 8.1 amended with sodium selenate. 
Table 5. Soil organic matter and Se content $(\mathrm{mg} / \mathrm{kg}$ dry weight) of lettuce and berseem crops grown in soils with a $\mathrm{pH}$ range of 6.5 to 8.1 at the end of the experiment. The mean $\pm \mathrm{SE}$ of five replicates is given.

\begin{tabular}{cccc}
\hline Soil Type & Cultivation & Soil Organic Matter(\%) & Se content(mg/kg DW) \\
\hline Acidic & Lettuce & $2.4 \pm 0.1$ & $20.8 \pm 3.7$ \\
& Berseem & $1.4 \pm 0.9$ & $78.4 \pm 7.5$ \\
Alkaline & Lettuce & $8.5 \pm 0.3$ & $4.8 \pm 0.3$ \\
& Berseem & $4.5 \pm 0.2$ & $9.4 \pm 0.4$ \\
\hline
\end{tabular}

More recently, Ferri et al. [35] found in a sandy alkaline soil amended with selenate, a significant reduction in Se content of lettuce leaves after the addition of organic substances (polysaccharide carboxymethylcellulose). Moreover, several studies have shown that Se applied into the soil are quickly immobilized by SOM forming water-insoluble complexes with organic compounds, and thus, less plant available Se ([31] and references therein). However, as previously suggested by Natasha et al. [27], very limited data is available regarding the speciation and molecular structure of Se bound to organic matter.

Ammonium bicarbonate-diethylenetriaminepentaacetic acid (AB-DTPA) extractable Se in the soil was related to $\mathrm{pH}$, with very low content for the acidic soil $(<0.004 \mathrm{mg} / \mathrm{kg})$, while in alkaline soil high available Se values were observed. According to Dhillon et al. [25], the ability of a certain extractant in evaluating the soil Se availability to plants depends on the type and nature of the soil.

Soltanpour and Workman [20] found that AB-DTPA can be used as a reliable of Se availability and toxicity reporting at the same time that AB-DTPA extracted about 1.5 times more available Se than hot water. According to their findings AB-DTPA Se $>0.1 \mathrm{mg} / \mathrm{kg}$ increased the Se content in alfalfa plants above of $5 \mathrm{mg} / \mathrm{kg}$. Ylaranta [36] reported extractable with hot water, soil Se concentrations of $2-27 \mu \mathrm{g} / \mathrm{kg}$, concentrations considered to be too low to produce crops with sufficient Se for human nutrition [37]. In our study, although no differences in available Se concentration between the crops in the acidic soil were observed, the high $\mathrm{pH}$ values of the alkaline soil with medium organic matter content, led to an increase in Se availability (Figure 4).

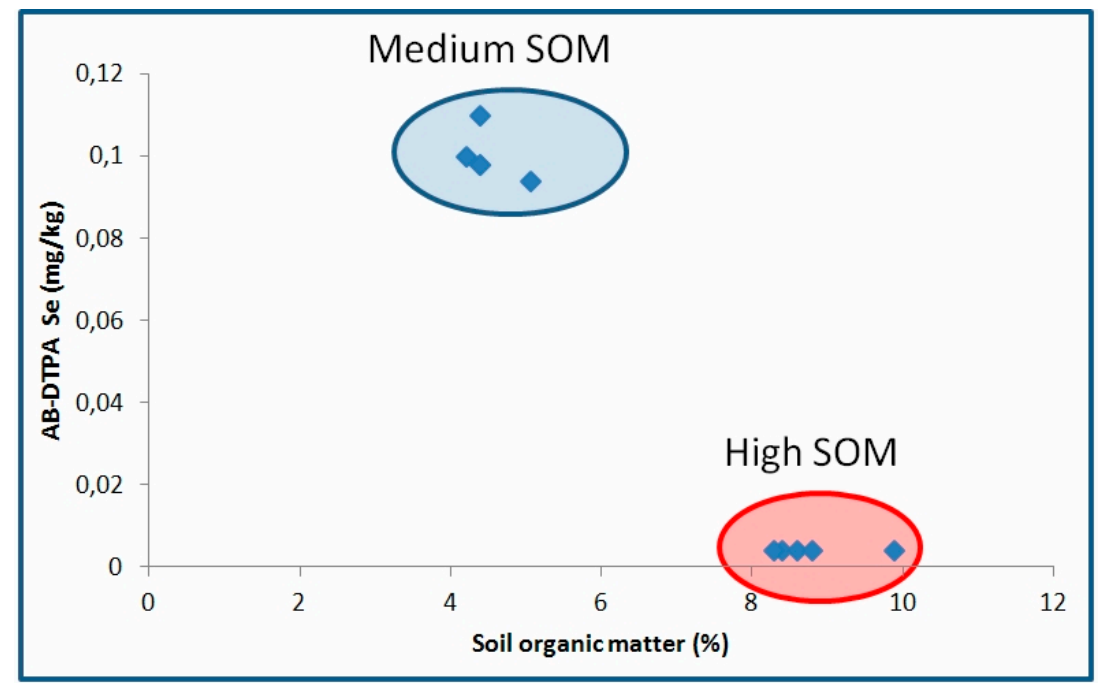

Figure 4. Relationship between available Se (AB-DTPA) and soil organic matter (SOM) content in the alkaline soil amended with sodium selenate.

In this case, the available Se concentration ranged from $0.094-0.11 \mathrm{mg} / \mathrm{kg}$ which was close to the WDEQ-LQD [38] marginal available Se level. At the highest organic matter level, however, available Se was similar to the acidic soil $(<0.004 \mathrm{mg} \mathrm{kg})$ as Se bioavailability rapidly decreases with increasing SOM content. Dhillon et al. [39] after greenhouse and field experiments concluded that the application 
of organic manures is as effective way to decrease the bioavailability of Se reducing the transfer of Se from soil to plant in seleniferous soils.

\section{Materials and Methods}

The experimental procedure was carried out in a greenhouse of the Agricultural University of Athens, under controlled environmental conditions. The test plants were Lactuca sativa L. and Trifolium alexandrinum L., as consumption's indicators of human, and animals, respectively. Vegetables were found to provide more than $85 \%$ of the average daily human dietary Se intake in seleniferous soils. Since lettuce is the most consumed leafy plant in many parts of the world, this crop can be used in as an efficient way of increasing intake of Se by humans. Two soil types (an alkaline amended with peat and acidic one) with different content of soil organic matter (Table 1) were chosen and polyethylene pots were filled with $2 \mathrm{~kg}$ of each of one with daily irrigation to keep soil moisture at $70 \%$ field capacity. The chemical form of Se was the sodium selenate $\left(\mathrm{Na}_{2} \mathrm{SeO}_{4} 1 \mathrm{M}\right)$ at the high dose of $4 \mathrm{mg} \mathrm{Se} / \mathrm{kg}$ as previously indicated by Hawkesford and Zhao [40]. As a control, plants grown without Se application were used. Moreover, no NPK fertilization was given during the experiment. The experiment was a completely randomized block design with three replicates for control plants and five replicates for treatment plants, totaling 32 pots.

In order to assess the effect of soil properties on Se uptake, the soil samples at the end of experiment, were recovered by gentle shaking and scraping the roots, air dried and sieved ( $2 \mathrm{~mm}$ ) to remove stones and plant residues. Particle-size distribution, calcium carbonate, $\mathrm{pH}$, organic matter, and exchangeable cations were determined according standard [41]. Briefly, the soil parameters were determined as follows: $\mathrm{pH}$ in a soil-distilled water paste $(1: 1)$ using a glass electrode meter, particle size analysis according to the Bouyoucos method, organic matter using the wet oxidation method with $\mathrm{K}_{2} \mathrm{Cr}_{2} \mathrm{O}_{7}-\mathrm{H}_{2} \mathrm{SO}_{4}$ and $\mathrm{FeSO}_{4} .7 \mathrm{H}_{2} \mathrm{O}$ titration method and the exchangeable cations, according to the method of $\mathrm{CH}_{3} \mathrm{COONH}_{4}$. Moreover, since P influence the Se uptake [42], the available P was determined according to the Olsen method. Ammonium bicarbonate-diethylenetriaminepentaacetic acid (AB-DTPA) extractable Se was determined according to Soltanpour and Workman [20] method. Briefly, $10 \mathrm{~g}$ soil was shaken with $20 \mathrm{~mL}$ of $1 \mathrm{M} \mathrm{NH}_{4} \mathrm{HCO}_{3}$ and $0.005 \mathrm{M}$ DTPA for $15 \mathrm{~min}$ on a reciprocating shaker, the soil suspension was centrifuged, and the supernatant was analyzed for Se. In most cases, the values of soil properties actually found after the experimental period, were different from the initial ones as a result of the effect of cultivation. This differentiation was more pronounced for soil organic matter values in the alkaline soil amended with peat under lettuce cultivation. Similarly, Kukkonen et al. [43] found statistically significant effects of crop plant (Carum carvi L.) on properties in a silt clay soil amended with peat.

At harvest the plants were separated into shoots and roots, followed washing with deionized water and placing in a laboratory oven for three days at approximately $60^{\circ} \mathrm{C}$ and then ground to a fine powder. For determination of Se, due to its high evaporating ability, the autoclave combustion of high pressure was used. The sample $(0.5 \mathrm{~g})$ was placed in cylindrical porcelain capsule, with 1 $\mathrm{mL}$ of hydrogen peroxide $\left(\mathrm{H}_{2} \mathrm{O}_{2}\right)$ and $6 \mathrm{~mL}$ of concentrated nitric acid $\left(\mathrm{HNO}_{3}\right)$. The solutions were transferred to volumetric flasks $(50 \mathrm{~mL})$ and the Se was determined by the ICP-MS spectrometry according to ASTM D5673 - 10 standard method [44].

Data processing performed by ANOVA at 95\% confidence using StatGraphics Centurion for Windows software as described by Petridis et al. [45].

\section{Conclusions}

Selenium fertilization of lettuce and berseem (Lactuca Sativa L. and Trifolium alexandrinum L., respectively) grown on an acidic and alkaline soil increased the plant Se content and, potentially, dietary intake of Se by humans and animals. Our results indicated that the effect of $\mathrm{pH}$ on Se uptake decreased as the soil organic matter content increased. In alkaline soils with medium levels of soil organic matter, a larger part of the Se, in the form of added selenate, seems to exist in a plant-available 
form, because an increase in $\mathrm{pH}$ decreases the amount of $\mathrm{pH}$-dependent binding sites, i.e., the positive charges on clay minerals and sesquioxides. However, an increase in SOM from $4.5 \%$ to $8.5 \%$ in the alkaline soil, led to a decrease in Se availability indicating that high levels of organic matter can restrict the role of soil $\mathrm{pH}$ of Se absorption by plants. Therefore, in accordance with earlier findings, raising the soil $\mathrm{pH}$ does not seem to be a suitable management practice increasing Se availability of soils rich in organic matter. The original Se concentration of both soils had no effect on Se uptake by lettuce and berseem whereas the application of sodium selenate results in higher Se content in berseem in relation to lettuce. Since additional soil properties such as redox potential, competing anions and microbial activity greatly affect Se availability, further studies are needed to confirm the effectiveness of Se fertilization strategy under field conditions and to elucidate the main mechanisms of Se uptake by plants.

Author Contributions: Conceptualization, D.G. and M.E.-E.; data curation, M.T., D.G. and M.E.-E.; formal analysis, M.T.; investigation, M.T. and M.E.-E.; methodology, M.T. and D.G.; validation, D.G.; writing-original draft preparation, MT.; writing - review and\& editing, D.G. All authors have read and agreed to the published version of the manuscript.

Funding: This research received no external funding.

Conflicts of Interest: The authors declare no conflict of interest.

\section{References}

1. Broadley, M.; White, P.J.; Bryson, R.J.; Meacham, M.C.; Bowen, H.C.; Johnson, S.E.; Hawkesford, M.J.; McGrath, S.P.; Zhao, F.-J.; Breward, N.; et al. Biofortification of UK food crops with selenium. Proc. Nutr. Soc. 2006, 65, 169-181. [CrossRef] [PubMed]

2. Kumar, S.B.; Priyadarsini, K.I. Selenium nutrition: How important is it? Biomed. Prev. Nutr. 2014, 4, 333-341. [CrossRef]

3. Cobo-Angel, C.; Wichtel, J.; Ceballos-Márquez, A. Selenium in milk and human health. Anim. Front. 2014, 4, 38-43. [CrossRef]

4. Moghadaszadeh, B.; Beggs, A.H. Selenoproteins and their impact on human health through diverse physiological pathways. Physiology 2006, 21, 307-315. [CrossRef]

5. Oldfield, J.E. Selenium World Atlas, Updated ed.; Selenium-Tellurium Development Association: Grimbergen, Belgium, 2002.

6. Hartikainen, H. Biogeochemistry of selenium and its impact on food chain quality and human health. J. Trace Elements Med. Biol. 2005, 18, 309-318. [CrossRef]

7. WHO. Global Health Risks: Mortality and Burden of Disease Attributable to Selected Major Risks. 2009. Available online: https://www.who.int/healthinfo/global_burden_disease/GlobalHealthRisks_report_full.pdf (accessed on 5 April 2019).

8. Fernandez-Martinez, A.; Charlet, L. Selenium environmental cycling and bioavailability: A structural chemist point of view. Rev. Environ. Sci. Biotechnol. 2009, 8, 81-110. [CrossRef]

9. Economou-Eliopoulos, M.; Eliopoulos, D.G. Selenium content of sulfide ores related to ophiolites of Greece. J. Environ. Pathol. Toxicol. Oncol. 1998, 17, 199-204.

10. Economou-Eliopoulos, M.; Eliopoulos, D.G.; Chryssoulis, S. A comparison of high-Au massive sulfide ores hosted in ophiolite complexes of the Balkan Peninsula with modern analogues: Genetic significance. Ore Geol. Rev. 2008, 33, 81-100. [CrossRef]

11. Johnsson, L. Selenium uptake by plants as a function of soil type, organic matter content and pH. Plant Soil 1991, 133, 57-64. [CrossRef]

12. Hasanuzzaman, M.; Hossain, M.A.; Fujita, M. Selenium in higher plants: Physiological role, antioxidant metabolism and abiotic stress tolerance. J. Plant Sci. 2010, 5, 354-375. [CrossRef]

13. Dhillon, K.; Dhillon, S. Distribution and management of seleniferous soils. Adv. Agron. 2003, 79, 119-184. [CrossRef]

14. Stephen, R.C.; Saville, D.J.; Watkinson, J.H. The effects of sodium selenate applications on growth and selenium concentration in wheat. New Zealand J. Crop Hortic. Sci. 1989, 17, 229-237. [CrossRef] 
15. Alfthan, G.; Eurola, M.; Ekholm, P.; Venäläinen, E.-R.; Root, T.; Korkalainen, K.; Hartikainen, H.; Salminen, P.; Hietaniemi, V.; Aspila, P.; et al. Effects of nationwide addition of selenium to fertilizers on foods, and animal and human health in Finland: From deficiency to optimal selenium status of the population. J. Trace Elem. Med. Biol. 2015, 31, 142-147. [CrossRef] [PubMed]

16. Gupta, M.; Gupta, S. An overview of selenium uptake, metabolism, and toxicity in plants. Front. Plant Sci. 2017, 7, 1-14. [CrossRef] [PubMed]

17. Bratakos, M.S.; Ioannou, P.V. The regional distribution of selenium in Greek cereals. Sci. Total Environ. 1989, 84, 237-247. [CrossRef]

18. Ramos, S.J.; Faquin, V.; Guilherme, L.R.G.; Castro, E.; Ávila, F.W.; Carvalho, G.; Bastos, C.; Oliveira, C. Selenium biofortification and antioxidant activity in lettuce plants fed with selenate and selenite. Plant Soil Environ. 2010, 56, 584-588. [CrossRef]

19. Mora, M.L.; Pinilla, L.; Rosas, A.; Cartes, P. Selenium uptake and its influence on the antioxidative system of white clover as affected by lime and phosphorus fertilization. Plant Soil 2008, 303, 139-149. [CrossRef]

20. Soltanpour, P.N.; Workman, S.M. Use of $\mathrm{NH}_{4} \mathrm{HCO}_{3}$-DTPA soil test to assess availability and toxicity of selenium to alfalfa plants. Commun. Soil Sci. Plant Anal. 1980, 11, 1147-1156. [CrossRef]

21. Bañuelos, G.; Zambrzuski, S.; Mackey, B. Phytoextraction of selenium from soils irrigated with selenium-laden effluent. Plant Soil 2000, 224, 251-258. [CrossRef]

22. Dimes, L.; Rendig, V.; Besgu, G.; Dong, A. Selenium uptake by subclover, ryegrass, and some Astragalus spp. In Selenium Contents in Animal and Human Food Crops grown in California; CA: Cooperative Extension University of California, Division of Agriculture and Natural Resources USA. Publication 3330, 19-24University of California Salinity/Drainage Task Force: Oakland, CA, USA, 1988.

23. Zhang, M.; Tang, S.; Huang, X.; Zhang, F.; Pang, Y.; Huang, Q.; Yi, Q. Selenium uptake, dynamic changes in selenium content and its influence on photosynthesis and chlorophyll fluorescence in rice (Oryza sativa L.). Environ. Exp. Bot. 2014, 107, 39-45. [CrossRef]

24. Puccinelli, M.; Malorgio, F.; Pezzarossa, B. Selenium enrichment of horticultural crops. Molecules 2017, 22, 933. [CrossRef] [PubMed]

25. Dhillon, K.S.; Rani, N.; Dhillon, S.K. Evaluation of different extractants for the estimation of bioavailable selenium in seleniferous soils of Northwest India. Soil Res. 2005, 43, 639-645. [CrossRef]

26. Fan, J.; Wang, R.; Hu, H.; Huo, G.; Fu, Q.; Zhu, J. Transformation and bioavailability of selenate and selenite added to a Nicotiana tabacum L. planting soil. Commun. Soil Sci. Plant Anal. 2015, 46, 1362-1375. [CrossRef]

27. Shahid, M.; Niazi, N.K.; Khalid, S.; Murtaza, B.; Bibi, I.; Rashid, M.I. A critical review of selenium biogeochemical behavior in soil-plant system with an inference to human health. Environ. Pollut. 2018, 234, 915-934.

28. Krystofova, O.; Adam, V.; Babula, P.; Zehnalek, J.; Beklova, M.; Havel, L.; Kizek, R. Effects of various doses of selenite on stinging nettle (Urtica dioica L.). Int. J. Environ. Res. Public Health 2010, 7, 3804-3815. [CrossRef]

29. Zhang, Y.; Pan, G.; Chen, J.; Hu, Q. Uptake and transport of selenite and selenate by soybean seedlings of two genotypes. Plant Soil 2003, 253, 437-443. [CrossRef]

30. Thavarajah, D.; Thavarajah, P.; Vial, E.; Gebhardt, M.; Lacher, C.; Kumar, S.; Combs, G.F. Will lentil (Lens culinaris Medik) yield and seed quality? Front. Plant Sci. 2015, 6, 356. [CrossRef]

31. Li, Z.; Liang, D.-L.; Peng, Q.; Cui, Z.; Huang, J.; Lin, Z. Interaction between selenium and soil organic matter and its impact on soil selenium bioavailability: A review. Geoderma 2017, 295, 69-79. [CrossRef]

32. Darcheville, O.; Février, L.; Haichar, F.; Berge, O.; Martin-Garin, A.; Renault, P. Aqueous, solid and gaseous partitioning of selenium in an oxic sandy soil under different microbiological states. J. Environ. Radioact. 2008, 99, 981-992. [CrossRef]

33. Bruggeman, C.; Maes, A.; Vancluysen, J. The interaction of dissolved Boom Clay and Gorleben humic substances with selenium oxyanions (selenite and selenate). Appl. Geochem. 2007, 22, 1371-1379. [CrossRef]

34. Jordan, N.; Marmier, N.; Lomenech, C.; Giffaut, E.; Ehrhardt, J.-J. Competition between selenium (IV) and silicic acid on the hematite surface. Chemosphere 2009, 75, 129-134. [CrossRef] [PubMed]

35. Ferri, T.; Petruzzelli, G.; Pezzarossa, B.; Santaroni, P.; Brunori, C.; Morabito, R. Study of the influence of carboxymethylcellulose on the absorption of selenium (and selected metals) in a target plant. Microchem. J. 2003, 74, 257-265. [CrossRef]

36. Ylaranta, T. Sorption of selenite and selenate in the soil. Ann. Agr. Fen. 1983, 22, 29-39. 
37. Gissel-Nielsen, G.; Gupta, U.C.; Lamand, M.; Westermarck, T. Selenium in soils and plants and its importance in livestock and human nutrition. Adv. Agron. 1984, 37, 397-460. [CrossRef]

38. WDEQ-LQD. Guideline No. 1, Soil and Overburden; Herschler Building: 122 West 25th Street, Cheyenne, WY, USA, 1984.

39. Dhillon, K.; Dhillon, S.; Dogra, R. Selenium accumulation by forage and grain crops and volatilization from seleniferous soils amended with different organic materials. Chemosphere 2010, 78, 548-556. [CrossRef]

40. Hawkesford, M.J.; Zhao, F.-J. Strategies for increasing the selenium content of wheat. J. Cereal Sci. 2007, 46, 282-292. [CrossRef]

41. Gasparatos, D.; Roussos, P.; Christofilopoulou, E.; Haidouti, C. Comparative effects of organic and conventional apple orchard management on soil chemical properties and plant mineral content under Mediterranean climate conditions. J. Soil Sci. Plant Nutr. 2011, 11, 105-117. [CrossRef]

42. Liu, H.; Shi, Z.; Li, J.; Zhao, P.; Qin, S.; Nie, Z. The impact of phosphorus supply on selenium uptake during hydroponics experiment of winter wheat (Triticum aestivum) in China. Front. Plant Sci. 2018, 9, 1-9. [CrossRef]

43. Kukkonen, S.; Palojärvi, A.; Räkköläinen, M.; Vestberg, M. Peat amendment and production of different crop plants affect earthworm populations in field soil. Soil Biol. Biochem. 2004, 36, 415-423. [CrossRef]

44. The American Society for Testing and Materials. ASTM D5673-10 Standard Test Method for Elements in Water by Inductively Coupled Plasma-Mass Spectrometry; ASTM International: West Conshohocken, PA, USA, 2010; Available online: www.astm.org (accessed on 1 April 2020).

45. Petridis, A.; Gasparatos, D.; Haidouti, C.; Paschalidis, C.; Zamanidis, P. Effects of nitrogen and boron fertilization on lettuce mineral nutrition in a calcareous soil. Commun. Soil Sci. Plant Anal. 2013, 44, 733-740. [CrossRef]

(C) 2020 by the authors. Licensee MDPI, Basel, Switzerland. This article is an open access article distributed under the terms and conditions of the Creative Commons Attribution (CC BY) license (http://creativecommons.org/licenses/by/4.0/). 